\title{
The adaptive potential of sweet cherry varieties (C. avium $L$.) under the conditions of Southern horticulture
}

\author{
Rimma Zaremuk*, and Yulia Dolya \\ Federal State Budget Scientific Institution «North Caucasian Federal Scientific Center of Horticulture, \\ Viticulture, Wine-making», 39 str. 40 Let Pobedy, Krasnodar, 350901, Russia
}

\begin{abstract}
The results of research on the stability of sweet cherry varieties of different ecological and geographical origin to low-temperature stresses in the Southern horticulture are presented. The aim of the research was to comprehensively assess the generative potential of sweet cherry varieties after stress factors affect and identify the most resistant varieties to the stressors. It is shown that the probability of occurrence of abnormal frosts (limiting) in the range of $-33.0^{\circ} \mathrm{C}$ or return spring frosts $-4.0-5.0^{\circ} \mathrm{C}$ in the Prikuban gardening zone of the Krasnodar Territory is $40 \%$ on average. It was found that abnormal frosts can affect sweet cherry plants at the beginning of the dormant period - in december, more often in the middle in February, less often at the beginning of the growing season - in march. The frequency of recurrent spring frosts affect during the blossoming period is high. The degree of ruin of the sweet cherry generative organs is determined by the type of stress, the limiting temperature and specificity of varieties. The obtained results confirmed that the sweet cherry varieties of local (domestic) breeding were more resistant to frosts and to early spring frosts. According to frost resistance, the sweet cherry varieties of Alaya, Volshebnitsa, Mak and Kavkazskaya are selected. According to the resistance to early spring frosts the varieties of Anons, Alaya, Volshebnitsa, Mak, Kavkazskaya, Sashenka, Demetra and the Dar Izobiliya are selected. According to the complex resistance to frost and to early spring frosts, the varieties of NCFSCHVW breeding of Alaya, Volshebnica, Mak and Kavkazskaya, are selected and recommended for creating the intensive, adaptive gardens in the South of Russia, and to a certain extent they will allow you to control the production potential of plantations of stone fruit crops in order to obtain the consistently high yield capacity of 20-25 t/ha.
\end{abstract}

\section{Introduction}

Against the background of changes in climatic environmental factors, an important task of horticulture is to increase in the adaptability of fruit plantations. The weather and climatic conditions of the Southern Region of Russia make it possible to cultivate the most of the fruit crops, however the horticultural practice shows that even under these conditions, many stone

\footnotetext{
* Corresponding author: zaremuk_rimma@mail.ru
} 
fruit crops are not resistant to a number of stresses, especially to low-temperature ones. This trend is associated with their biological characteristics. Against the background of warm winters and a short period of cold, a premature plant exit from a state of dormancy and an early beginning of the growing season are provoked, which increasing the possibility of freezing the generative organs of fruit crops, including the stone fruit crops $[1,2,3]$.

Sweet cherry is one of the most popular stone fruit crops, but it is more susceptible to stresses than others. The main damage and ruin of the generative organs of sweet cherry are observed more often at two stages of its development - during the dormant period and during the blossoming period. According to scientists, the maximum adaptability potential of sweet cherry is "involved" in the period of deep dormancy, the duration of which for fruit plants is determined by low temperatures and day duration $[4,5]$, so the dormancy is a natural mechanism for protecting the generative organs of fruit plants from various types of frost [1, 6]. It has been proved that during this period, the anther tissues, being at the stage of primary archesporia, are more resistant to frost, and the generative organs of the sweet cherry are able to maintain their viability at a temperature of $-28.0^{\circ} \mathrm{C}[7,8]$. According to the results of some studies, the effect of negative temperatures the blossom buds is different, since the ice crystals are formed primarily in some tissues of the blossom, for this reason the pistil and ovules are most sensitive to frosts and slight frosts $[9,10,11]$.

It is recognized that an important stage in the implementation of the adaptive potential of sweet cherry is the blossoming period, when spring slight frosts often occur. Early studies made it possible to establish that when spring frosts exposed, the open sweet cherry flowers are perished at a temperature of $-2.0-2.2{ }^{\circ} \mathrm{C}$, the buds are perished at $-3.6-4.5^{\circ} \mathrm{C}[7,8]$. It was also revealed that the blossoms which have opened in cold weather are more frostresistant than those that have blossomed at high air temperatures [6,12]; sweet cherry flowers, slightly affected by spring early frosts, can recover and continue their development [9]. So, if the pistil turns brown after freezing, and darkened ovules are visible on the cut of the ovary, the fertilization process does not occur $[11,13]$, and if pollination becomes possible, it can lead to a change in the shape, appearance and size of the fruit $[14,15]$.

The above research results indicate a significant effect of temperature stresses the adaptive potential of sweet cherry, but do not give a picture of variety specificity. Today, there is not enough information on the resistance of promising varieties, in particular, to frost and spring slight frosts. Taking into account the fact that the variety is the main element of the cultivation technology and the instrument for control adaptability, the new knowledge is needed about the conformities and peculiarities of the yield formation by sweet cherry varieties under the emerging extreme conditions. It is obvious that the targeted selection of varieties that are resistant to stress, including low-temperature is one of the ways to increase in the productivity of plantations, that is an urgent scientific direction, which allows you to improve the assortment of sweet cherries with new resistant and productive varieties.

\section{Materials and methods}

The studies were carried out in 2006-2020 in the Prikubanskaya gardening zone of the Krasnodar Territory on the basis of the genetic collection (collective use center) NCFSCHVW. The objects of research were 18 varieties of sweet cherry of various ecological and geographical origin, including 9 varieties of local breeding (NCFSCHVW) - Alaya, Dar Izobiliya, Volshebnitsa, Demetra, Rubinovaya Kubani, Sashenka, Kavkazskaya, Krasnodarskaya Ranniya, Mak, 9 introduced - Anons, Valeriy Chkalov, Polyanka, Kashtanka, Krupnoplodnaya, Melitopolskaya Ranniya, Melitopolskaya Chernaya (Ukraine), Franz Joseph (Czech), Frantsuzskaya Chernaya (Western Europe). To assess the degree of damage, by the percentage of viable and frozen fruit buds after frost affect, 60 fruit buds were taken from one tree in 3 replicates, from different sides of the lower and upper branches. 
The sample size in anomalous years was 3000 - 3200 fruit buds. After spring slight frosts, the selection of 100 buds from one tree in 3 replicates was carried out in 1-3 days after frost affect. The sample size was 5000-5400 flowers. Morphological examination of fruit buds was carried out using a light microscope (Olympus BX41, Olympus Corporation, Japan). Statistical processing of the data was carried out in the standard Microsoft Excel software package (2013), where the following indicators were calculated: arithmetic average $\left(\mathrm{X}_{\text {average }}\right)$, standard deviation (SD), and $\mathrm{HCP} 05$ with a significant probability of $95 \%$. The coefficient of variation $(\mathrm{Cv}, \%)$ was calculated using the formula $\mathrm{Cv}=\mathrm{SD} / \mathrm{X}_{\text {average }} \mathrm{x} 100 \%$.

\section{Results and discussion}

Taking into account the above, the research focused on two types of stresses: frosts (2006, $2007,2016)$, recurrent spring slight frosts $(2009,2013,2020)$ against the background of warm frost-free winters that provoked early and "rapid" development of sweet cherry plants. Analysis of temperature stresses and assessment of resistance to them of sweet cherry varieties made it possible to establish that the probability of abnormal frosts within the range of $-33.0^{\circ} \mathrm{C}$ or return spring frosts $-4.0-5.0^{\circ} \mathrm{C}$ in the Krasnodar Territory is on average $40 \%$. The last five years (2015-2020) can be characterized as abnormally warm, when the required amount of negative temperatures did not accumulate for the full-fledged period of sweet cherry varieties hardening. In 2006 , an abnormal decrease in temperature to $-33.0^{\circ} \mathrm{C}$ was noted, which have led to the mass period of flower buds in all sweet cherry varieties, as evidenced by indicator with the low variation rate $(\mathrm{Cv}=4.7 \%)$. So $100 \%$ perish of generative organs was noted in the introduced varieties of Valeriy Chkalov, Kashtanka, Krupnoplodnaya, Franz Joseph, Melitopolskaya Ranniya, Polyanka, etc. Freezing of fruit buds at the level of $90 \%$ was found in the local varieties of Alaya, Volshebnitsa, Dar Izobiliya, Kavkazskaya, Mak, which had a yield of 4.5-5.0 kg / tree (Figure 1,2). At the same time, a direct correlation between the percentage of fruit buds perish and the degree of frost affect has been proven reliably $\left(\mathrm{R}^{2}=0.986\right)$. At the end of February 2007, a sharp drop in temperature to $-22.0-25.0^{\circ} \mathrm{C}$ caused different freezing degree (10-90\%) of fruit buds of sweet cherry varieties, which is also evidenced by a high variation rate of $\mathrm{Cv}=51.3 \%$. A comparatively high resistance to frost (10-20\% of perished buds) was observed in the local sweet cherry varieties of Alaya, Sashenka, Kavkazskaya, and introduced variety of - Anons, the yield of these varieties was $35-40 \mathrm{~kg} /$ tree (Figure 1, Table 1).

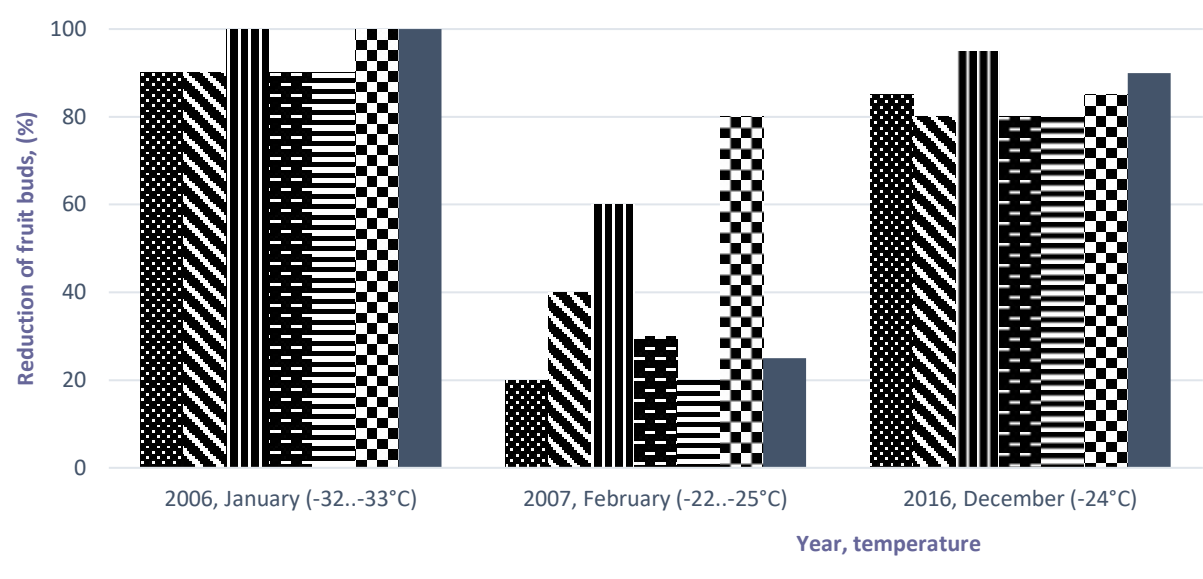


Fig. 1. Percentage of ruin of sweet cherry fruit buds

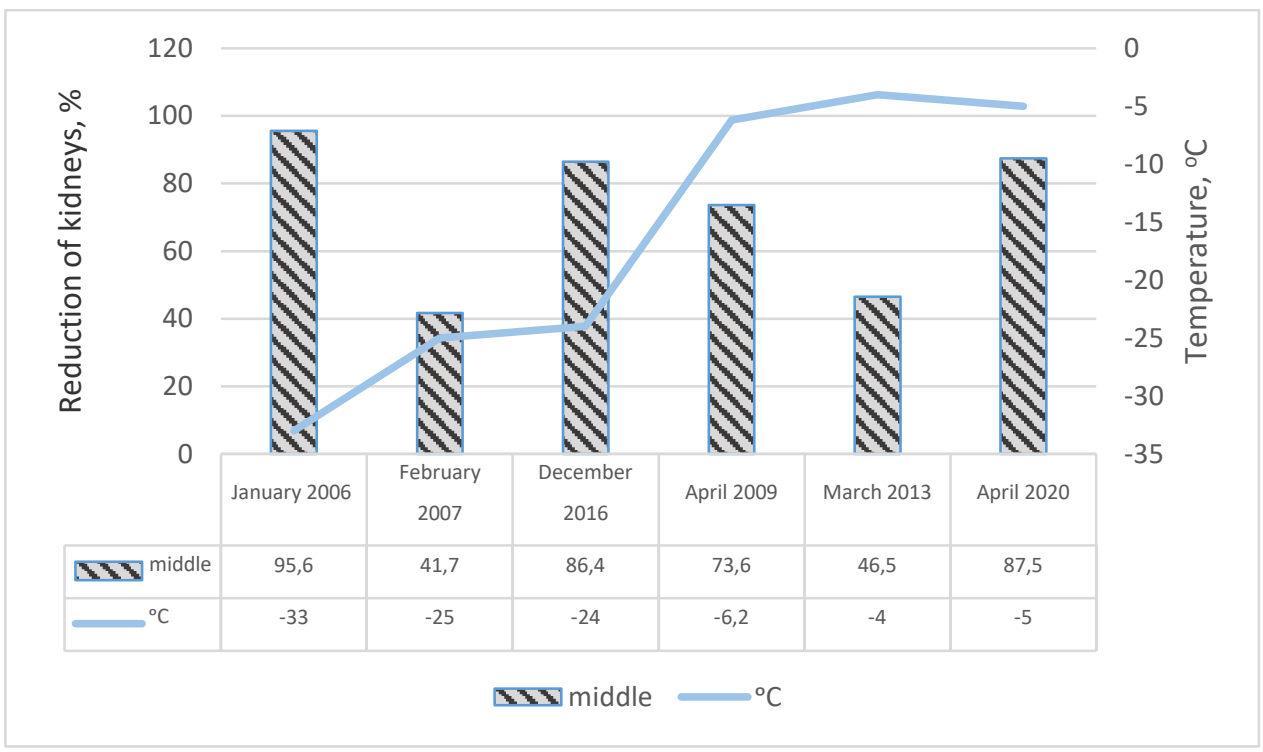

Fig. 2. The degree of reduction of sweet cherry fruit buds under the influence of low-temperature stress (Krasnodar)

Decrease in air temperature to $-24.0^{\circ} \mathrm{C}$ in December 2016, at the beginning of forced dormancy period, have led to the ruin of $80-90 \%$ of fruit buds in all cherry varieties. However, against this background also local varieties of Alaya, Volshebnitsa, Mak were identified, as well as the introduced one - Krupnoplodnaya, which formed a yield of 6.0-6.5 $\mathrm{kg} /$ tree, and it allow us to relaite the resistance of these varieties to the first component of winter hardiness of fruit crops (Table 1,2).

Table 1. Reduction of fruit buds of sweet cherry different varieties under conditions of exposure to low-temperature stress (Krasnodar)

\begin{tabular}{|c|c|c|c|c|c|c|c|}
\hline \multirow[b]{2}{*}{ Variety } & \multicolumn{7}{|c|}{ Perish of fruit buds, $\%$} \\
\hline & $\begin{array}{c}2006, \\
\text { January } \\
(-32- \\
\left.33^{\circ} \mathrm{C}\right)\end{array}$ & $\begin{array}{c}2007, \\
\text { February } \\
(-22- \\
\left.25^{\circ} \mathrm{C}\right)\end{array}$ & $\begin{array}{c}2009, \\
\text { April } \\
(- \\
\left.6.2^{\circ} \mathrm{C}\right)\end{array}$ & $\begin{array}{c}2013, \\
\text { March } \\
(-3- \\
\left.4^{\circ} \mathrm{C}\right)\end{array}$ & $\begin{array}{c}2016, \\
\text { December } \\
\left(-24^{\circ} \mathrm{C}\right)\end{array}$ & $\begin{array}{c}2020, \\
\text { April } \\
(-4- \\
\left.5^{\circ} \mathrm{C}\right)\end{array}$ & $\begin{array}{c}\mathrm{X} \\
\text { average }\end{array}$ \\
\hline \multicolumn{8}{|c|}{ Varieties of NCFSCHVW breeding } \\
\hline \multicolumn{8}{|l|}{ early varieties: } \\
\hline $\begin{array}{l}\text { Krasnodarskaya } \\
\text { Ranniya }\end{array}$ & 95 & 65 & 85 & 55 & 90 & 95 & 81.0 \\
\hline Kavkazskaya (st.) & 90 & 20 & 60 & 40 & 85 & 85 & 62.5 \\
\hline Sashen'ka & 95 & 20 & 60 & 50 & 85 & 85 & 65.8 \\
\hline \multicolumn{8}{|l|}{ middle varieties: } \\
\hline Volshebnitsa & 90 & 40 & 70 & 45 & 80 & 80 & 67.5 \\
\hline Demetra & 100 & 60 & 70 & 40 & 95 & 100 & 77.5 \\
\hline $\begin{array}{l}\text { Rubinovaya } \\
\text { Kubani }\end{array}$ & 95 & 40 & 90 & 45 & 90 & 85 & 74.0 \\
\hline late varieties: & & & & & & & \\
\hline
\end{tabular}




\begin{tabular}{|c|c|c|c|c|c|c|c|}
\hline Alaya & 90 & 20 & 60 & 40 & 80 & 90 & 60.0 \\
\hline Dar Izobiliya & 90 & 30 & 60 & 40 & 85 & 85 & 63.0 \\
\hline Mak & 90 & 30 & 60 & 45 & 80 & 80 & 64.0 \\
\hline \multicolumn{8}{|c|}{ Introduced varieties } \\
\hline \multicolumn{8}{|l|}{ early varieties: } \\
\hline Valeriy Chkalov & 100 & 40 & 75 & 52 & 90 & 95 & 75.0 \\
\hline Kashtanka & 100 & 90 & 85 & 55 & 90 & 100 & 86.0 \\
\hline $\begin{array}{l}\text { Melitopol'skaya } \\
\text { Ranniya }\end{array}$ & 100 & 80 & 90 & 50 & 85 & 95 & 83.0 \\
\hline \multicolumn{8}{|l|}{ middle varieties: } \\
\hline Anons & 90 & 10 & 65 & 45 & 90 & 80 & 65 \\
\hline $\begin{array}{l}\text { Melitopol'skaya } \\
\text { Chernaya }\end{array}$ & 95 & 50 & 80 & 55 & 85 & 85 & 76.0 \\
\hline Frants Iosif & 100 & 50 & 95 & 40 & 90 & 85 & 77.0 \\
\hline \multicolumn{8}{|l|}{ late varieties: } \\
\hline Krupnoplodnaya & 100 & 30 & 70 & 40 & 80 & 85 & 69.0 \\
\hline Polyanka & 100 & 40 & 70 & 55 & 85 & 90 & 73.0 \\
\hline $\begin{array}{l}\text { Frantsyzskaya } \\
\text { Chernaya }\end{array}$ & 100 & 25 & 80 & 45 & 90 & 95 & 72.5 \\
\hline $\mathrm{LSD}_{0,5}$ & 1.5 & 3.2 & 2.4 & 1,7 & 1.5 & 1.8 & - \\
\hline $\mathrm{SD}, \%$ & 4.5 & 21.4 & 11.9 & 5.9 & 4.5 & 8.4 & - \\
\hline X average: & 95.6 & 41.7 & 73.6 & 46.5 & 86.4 & 87.5 & - \\
\hline $\mathrm{Cv}, \%$ & 4.7 & 51.3 & 16.0 & 12.9 & 5.2 & 9.6 & - \\
\hline
\end{tabular}

It is known that the period when the plants are going out from dormancy is quite intense, when temperatures are still unstable, and winter hardiness is sharply reduced. At the beginning of the growing season, which in the South of Russia begins in late February - early April, the slight decreases in temperature are possible, that can cause more serious damage than winter frosts, since the plants are already out of dormancy. So, in the first ten days of March 2013, when to return frosts affect $\left(-3.0-4.0^{\circ} \mathrm{C}\right)$ in the phenophase "spreading scales", more than half of the fruit buds $50-55 \%$ perished in the introduced varieties of Valeriy Chkalov, Kashtanka, Melitopol'skaya Chernaya, Polyanka, as well as local varieties of Sashen'ka, Krasnodarskaya Ranniya, which significantly reduced the yield of these varieties to $10.0-15.0 \mathrm{~kg} /$ tree. The most resistant varieties were Alaya and Mak, which in such unfavorable conditions had a yield of $20.0 \mathrm{~kg} /$ tree.

In the South of the country, the spring stage of sweet cherry development is associated with annual return frosts, which often lead to the complete ruin of the crop. During the period of our research, the frosts in $2009\left(-6.2^{\circ} \mathrm{C}\right)$ and $2020\left(-4.0-5.0^{\circ} \mathrm{C}\right)$ were the most destructive in the spring. Freezing of the generative organs was significant, that is explained not only by the affect of freezing, but also by the fact that the fruit buds continued in phenological development and were in the phases of "white bud" and "blossoming". In our opinion, this stage is the most critical, since the generative organs during this period of development are the least stable, and correspondingly more vulnerable. The least adapted to such conditions in 2009 were among the local varieties - Rubinovaya Kubani and Krasnodarskaya Ranniya, among introduced varieties - Kashtanka, Melitopol'skaya Ranniya, Frants Iosif, with a high reduction of $85-95 \%$ of generative buds and a low yield of $1.5-2.5 \mathrm{~kg} /$ tree. The varieties of Alaya, Dar Izobiliya, Mak, Kavkazskaya, Sashen'ka of domestic breeding suffered to a lesser extent, the ruin of fruit buds was $60 \%$, which allowed them to form a yield of up to $8.5 \mathrm{~kg} /$ tree.

In April 2020, in the sweet cherry blossom phenophase in all fruit zones of the Krasnodar Territory, the slight frosts $\left(-4 \cdot 0-5 \cdot 0^{\circ} \mathrm{C}\right)$ were noted, which have led to the mass ruin of fruit 
buds, respectively and the harvest of many varieties. The varieties of Demetra and Kashtanka with $100 \%$ ruin of fruit buds, the yield was absent. A number of local varieties of Volshebnitsa, Kavkazskaya, Mak, Rubinovaya Kubani, and foreign varieties - Anons, Krupnoplodnaya, Frants Iosif, had a yield of $3.0-4.0 \mathrm{~kg} /$ tree, that is why these varieties are insignificat resistat to spring slight frosts at a late stage of development (Table 1,2).

Table 2. Yield of sweet cherry varieties of various ecological and geographical origin under conditions of affect low-temperature stress (Krasnodar)

\begin{tabular}{|c|c|c|c|c|c|c|}
\hline \multirow[b]{2}{*}{ Variety } & \multicolumn{6}{|c|}{ Yield in different years of research, $\mathrm{kg} /$ tree } \\
\hline & $\begin{array}{c}2006, \\
\text { January } \\
(-32- \\
\left.33^{\circ} \mathrm{C}\right)\end{array}$ & $\begin{array}{c}2007, \\
\text { February } \\
\left(-22-25^{\circ} \mathrm{C}\right)\end{array}$ & $\begin{array}{c}2009 \\
\text { April } \\
\left(-6.2^{\circ} \mathrm{C}\right)\end{array}$ & $\begin{array}{c}2013 \\
\text { March } \\
\left(-3-4^{\circ} \mathrm{C}\right)\end{array}$ & $\begin{array}{c}2016, \\
\text { December } \\
\left(-24^{\circ} \mathrm{C}\right)\end{array}$ & $\begin{array}{c}2020, \\
\text { April } \\
(-4- \\
\left.5^{\circ} \mathrm{C}\right)\end{array}$ \\
\hline \multicolumn{7}{|c|}{ Varieties of NCFSCHVW breeding } \\
\hline Alaya & $5.0 \pm 2.0$ & $40.0 \pm 5.0$ & $8.0 \pm 3.0$ & $20.0 \pm 4.0$ & $6.5 \pm 2.5$ & $2.0 \pm 0.5$ \\
\hline $\begin{array}{l}\text { Volshebnits } \\
\text { a }\end{array}$ & $5.0 \pm 2.5$ & $20.0 \pm 3.5$ & $6.0 \pm 1.5$ & $17.0 \pm 3.0$ & $6.0 \pm 1.5$ & $3.5 \pm 1.5$ \\
\hline $\begin{array}{l}\text { Dar } \\
\text { Izobiliya }\end{array}$ & $4.5 \pm 1.5$ & $25.0 \pm 5.0$ & $7.0 \pm 2.5$ & $17.0 \pm 3.5$ & $5.5 \pm 1.0$ & $1.5 \pm 0.5$ \\
\hline Demetra & $0.0 \pm 0.0$ & $12.0 \pm 4.0$ & $5.5 \pm 1.5$ & $15.0 \pm 3.0$ & $3.5 \pm 0.5$ & $0.0 \pm 0.0$ \\
\hline $\begin{array}{l}\text { Krasnodarsk } \\
\text { aya Ranniya }\end{array}$ & $1.5 \pm 0.5$ & $12.0 \pm 1.5$ & $2.0 \pm 1.5$ & $13.5 \pm 2.5$ & $5.0 \pm 1.5$ & $1.0 \pm 0.0$ \\
\hline $\begin{array}{l}\text { Kavkazskay } \\
\text { a (st.) }\end{array}$ & $5.5 \pm 1.0$ & $35.0 \pm 5.0$ & $7.0 \pm 2.0$ & $18.0 \pm 2.5$ & $5.5 \pm 2.0$ & $3.0 \pm 0.5$ \\
\hline Mak & $5.0 \pm 0.5$ & $27.0 \pm 2.0$ & $7.5 \pm 1.5$ & $20.0 \pm 4.0$ & $6.5 \pm 2.5$ & $3.5 \pm 0.5$ \\
\hline Sashen'ka & $1.0 \pm 0.5$ & $35.0 \pm 3.5$ & $8.5 \pm 2.5$ & $15.0 \pm 2.0$ & $5.5 \pm 2.0$ & $2.5 \pm 1.0$ \\
\hline $\begin{array}{l}\text { Rubinovaya } \\
\text { Kubani }\end{array}$ & $2.5 \pm 0.5$ & $18.0 \pm 2.0$ & $1.5 \pm 1.5$ & $17.5 \pm 2.5$ & $4.0 \pm 1.5$ & $3.0 \pm 1.0$ \\
\hline \multicolumn{7}{|c|}{ Introduced varieties } \\
\hline $\begin{array}{l}\text { Melitopol'sk } \\
\text { aya } \\
\text { Chernaya }\end{array}$ & $1.0 \pm 0.5$ & $20.0 \pm 3.0$ & $3.0 \pm 1.0$ & $10.0 \pm 2.5$ & $5.0 \pm 2.0$ & $2.0 \pm 0.5$ \\
\hline Anons & $4.5 \pm 0.5$ & $35.0 \pm 4.5$ & $6.0 \pm 1.5$ & $14.5 \pm 2.0$ & $4.5 \pm 0.5$ & $3.5 \pm 1.0$ \\
\hline $\begin{array}{l}\text { Valeriy } \\
\text { Chkalov }\end{array}$ & $0.0 \pm 0.0$ & $20.0 \pm 5.0$ & $3.5 \pm 0.5$ & $12.5 \pm 4.0$ & $3.5 \pm 0.5$ & $1.5 \pm 0.5$ \\
\hline Kashtanka & $0.0 \pm 0.0$ & $5.0 \pm 0.0$ & $2.5 \pm 1.0$ & $13.0 \pm 2.0$ & $4.0 \pm 1.5$ & $0.0 \pm 0.0$ \\
\hline $\begin{array}{l}\text { Krupnoplod } \\
\text { naya }\end{array}$ & $0.0 \pm 0.0$ & $27.0 \pm 2.5$ & $6.5 \pm 1.5$ & $18.5 \pm 2.5$ & $6.0 \pm 1.5$ & $4.0 \pm 1.0$ \\
\hline $\begin{array}{l}\text { Melitopol'sk } \\
\text { aya Ranniya }\end{array}$ & $0.0 \pm 0.0$ & $7.0 \pm 1.5$ & $2.0 \pm 0.5$ & $14.0 \pm 2.0$ & $4.5 \pm 0.5$ & $1.0 \pm 0.0$ \\
\hline Polyanka & $0.0 \pm 0.0$ & $23.0 \pm 3.0$ & $4.0 \pm 0.5$ & $10.0 \pm 4.0$ & $4.0 \pm 0.5$ & $2.0 \pm 0.5$ \\
\hline $\begin{array}{l}\text { Frantsyzska } \\
\text { ya Chernaya }\end{array}$ & $0.0 \pm 0.0$ & $20.0 \pm 2.0$ & $3.5 \pm 1.0$ & $14.0 \pm 2.0$ & $5.0 \pm 1.5$ & $0.5 \pm 0.0$ \\
\hline Frants Iosif & $0.0 \pm 0.0$ & $20.0 \pm 5.0$ & $1.5 \pm 0.5$ & $15.0 \pm 3.5$ & $3.5 \pm 0.5$ & $3.0 \pm 0.5$ \\
\hline $\operatorname{LSD}_{0,5}$ & 1.0 & 1.9 & 0.9 & 1.0 & 0.6 & 0.7 \\
\hline $\mathrm{SD}, \%$ & 2.25 & 9.92 & 2.4 & 2.9 & 1.0 & 1.3 \\
\hline $\mathrm{X}$ average: & 1.97 & 22.8 & 4.8 & 15.3 & 4.9 & 2.1 \\
\hline $\mathrm{Cv}, \%$ & 1.14 & 43.6 & 50.3 & 19.4 & 20.7 & 60.0 \\
\hline
\end{tabular}

\section{Conclusion}


Thus, studies carried out against the background of low-temperature stresses affect during the period of maximum realization of the adaptive potential of sweet cherry varieties made it possible to establish that a high degree of damage to the generative organs of sweet cherry was at two stages of its development - the dormant period and the blossoming period. The probability of abnormal frosts of $-33.0^{\circ} \mathrm{C}$ (which are the limiting ones for sweet cherry) or returned spring slight frosts of $-4.0-6.0^{\circ} \mathrm{C}$ (which are fatal for flowers) in the conditions of Southern horticulture is $40 \%$. The frost can affect the plant at the beginning of the dormant period - in December and in the middle of this period - in February, as well as at the beginning of the growing season. Returning spring slight frosts often occur during the period of bud formation, less often - during the period of mass blossoming.

The analysis carried out shows that the ruin of the generative organs depend on the degree of the damaging factor, that are absolute temperature and variety specifics. It has been confirmed that varieties of local breeding are more resistant to different types of stresses under the conditions of Southern gardening. Against the background of the stresses studied, the sufficiently resistant varieties of sweet cherry of local breeding to frosts during the dormant period were identified - Alaya, Volshebnitsa, Mak, Kavkazskaya. The varieties of Alaya, Volshebnitsa, Mak, Kavkazskaya, Sashenka, Demetra and Dar Izobiliya almost every year were characterized by resistance to spring slight frosts. According to the complex resistance to both frost and spring slight frosts, the varieties of Alaya, Volshebnitsa, Mak and Kavkazskaya of NCFSCHVW breeding are selected.

The selected domestic varieties of sweet cherry make it possible to create the intensive and adaptive plantations under the conditions of Southern horticulture and, to a certain extent, manage the adaptive productive potential of orchards in order to obtain consistently high yields of sweet cherry at the level of 15-20 t/he.

\section{References}

1. J. A. Campoy, D. Ruiz., J. Egea, Sci. Hortic., 130, 357-372 (2011). https://doi.org/10.1016/j.scienta.2011.07.011

2. J. A. Campoy, D. Ruiz, N. Cook, L. Allderman, J. Egea, S. Afr. J. Bot, 77, 618-630 (2011). https://doi.org/10.1016/j.sajb.2010.12.006

3. C. J. Atkinson, R. M. Brennan, H. G. Jones, Environ. Exp. Bot., 91, 48-62 (2013). https://doi.org/10.1016/j.envexpbot.2013.02.004

4. F.-M. Chmielewski, K.-P. Götz, Agric. For. Meteorol., 218-219, 85-91 (2016). https://doi.org/10.1016/j.agrformet.2015.11.022

5. H. Kaufmann, M. Blanke, J. Plant. Physiol., 218, 1-5 (2017). https://doi.org/10.1016/j.jplph.2017.07.004

6. E. Fadón., M. Herrero, J. Rodrigo, Sci. Hortic., 192, 141-147 (2015). https://doi.org/10.1016/j.scienta.2015.05.027

7. T. A. Gannouni, J. A. Campoy, J. Quero-García, T. Barreneche, A. Arif, A. Albouchi, Y. Ammari, Sci. Hortic., 219, 272-279 (2017). https://doi.org/10.1016/j.scienta.2017.03.013

8. E. Fadon, E. Fernandes, H. Behn, E. Luedeling, Agronomy, 10(2), 241 (2020). https://doi.org/10.3390/agronomy10020241

9. M. R. Salazar-Gutierrez, B. Chaves, J. Anothai, M. Whiting, G. Hoogenboom, Sci. Hortic., 172, 161-167 (2014). https://doi.org/10.1016/j.scienta.2014.04.002

10. K.-P. Götz, F.-M. Chmielewski, K. Gödeke, K. Wolf, E. Jander, S. Sievers, T. Homann, G. Huschek, H. M. Rawel, Sci. Hortic., 222, 102-110 (2017). https://doi.org/10.1016/j.scienta.2017.05.001

11. K.-P. Götz, F.-M. Chmielewski, T. Homan, G. Huschek, P. Matzneller, H. M. Rawel, Sci. Hortic., 172, 183-190 (2014). https://doi.org/10.1016/j.scienta.2014.04.012 
12. A. Khadivi, M. Mohammadi, K. Asgari, Sci. Hortic., 257, 108719 (2019). https://doi.org/10.1016/j.scienta.2019.108719

13. E. Maulión, G. H. Valentini, L. Kovalevski, M. Prunello, L. L. Monti, M. E. Daorden, M. Quaglino, G. Domingo, L. Cervigni, Sci. Hortic., 177, 112-117 (2014). https://doi.org/10.1016/j.scienta.2014.07.042

14. M. J. Serradilla, A. Martín, S. Ruiz-Moyano, A. Hernández, M. López-Corrales, M. de $\begin{array}{lllll}\text { G. Córdoba, Food Chemistry, 133(4), 1551-1559 (2012). } & \end{array}$ https://doi.org/10.1016/j.foodchem.2012.02.048

15. A. A Wani, P. Singh, K. Gul, M. H. Wani, H. C. Langowski, Food Packaging and Shelf Life, 1 (1), 86-99 (2014). https://doi.org/10.1016/j.fpsl.2014.01.005 